\title{
Salinity effect on nutritional value, chemical composition and bioactive compounds content of Cichorium spinosum $\mathrm{L}$.
}

\author{
Spyridon A. Petropoulos ${ }^{\mathrm{a}, *}$, Efi Levizou ${ }^{\mathrm{b}}$, Georgia Ntatsi ${ }^{\mathrm{c}}$, Ângela Fernandes ${ }^{\mathrm{d}}$, Konstantinos Petrotos ${ }^{\mathrm{e}}$, \\ Konstantinos Akoumianakis ${ }^{\mathrm{c}}$, Lillian Barros ${ }^{\mathrm{d}}$, Isabel C.F.R. Ferreira ${ }^{\mathrm{d}, *}$ \\ a Laboratory of Vegetable Production, University of Thessaly, Fytokou Street, 38446 N. Ionia, Magnissia, Greece \\ ${ }^{\mathrm{b}}$ Laboratory of Weed Science, University of Thessaly, Fytokou Street, 38446 N. Ionia, Magnissia, Greece \\ ${ }^{c}$ Laboratory of Vegetable Production, Agricultural University of Athens, Iera Odos 75, 11855 Athens, Greece \\ d Mountain Research Centre (CIMO), ESA, Polytechnic Institute of Bragança, Campus de Santa Apolónia, 1172, 5300-253 Bragança, Portugal \\ ${ }^{\mathrm{e}}$ Department of Biosystems Engineering, Technological Educational Institute of Thessaly, 41110 Larissa, Greece
}

\section{A R T I C L E I N F O}

Article history:

Received 4 March 2016

Received in revised form 4 July 2016

Accepted 11 July 2016

Available online 12 July 2016

Chemical compounds studied in this article: 5-O-Caffeoylquinic acid (PubChem CID: 5315832)

Caftaric acid (PubChem CID: 6440397)

Cichoric acid (PubChem CID: 5281764)

Kaempferol 3-glucuronide (PubChem CID: 5318759)

Quercetin 3-O- $\beta$-D-glucuronide (PubChem

CID: 12004528)

Keywords:

Bioactive compounds

Edible herbs

Nutrients

Saline conditions

Salt stress

Stamnagathi

\begin{abstract}
A B S T R A C T
Soil salinization is an increasing problem for many areas throughout the world that renders prohibitive vegetables and crop production in general. In the present study, Cichorium spinosum L. plants were grown under saline conditions in order to evaluate chemical composition and bioactive compounds content of their leaves. Salinity increase resulted in significant changes of macro and micro-nutrients content (nutritional value, sugars, fatty acids, minerals, ascorbic acid and tocopherols), whereas the concentration of phenolic compounds was not significantly affected. Chicoric and 5-O-caffeoylquinic acid were the most abundant phenolic acids. In contrast, antioxidant activity and mineral composition were beneficially affected by mid-to-high and high salinity levels. In conclusion, $C$. spinosum can be cultivated under saline conditions without compromising the quality of the final product, especially in semi-arid areas where irrigation water is scarce and/or of low quality due to high content of $\mathrm{NaCl}$ (coastal areas or areas where underground water is saline).
\end{abstract}

(c) 2016 Elsevier Ltd. All rights reserved.

\section{Introduction}

Soil salinity is an ever-growing degradation process that makes prohibitive the cultivation of vegetables in many areas and especially semi-arid areas in the Mediterranean basin. Nowadays, almost 20\% percent of the total arable land and 50\% of irrigated land is degraded due to high salinity problems (Zhu, 2001), mostly due to irrigation water or underground water of low quality. The use of saline or semi-saline water for irrigation purposes results

\footnotetext{
* Corresponding authors at: University of Thessaly, School of Agricultural Sciences, Fytokou Street, 38446 N. Ionia, Magnissia, Greece (S.A. Petropoulos).

E-mail addresses: fangio57gr@gmail.com (S.A. Petropoulos), iferreira@ipb.pt (I.C.F.R. Ferreira)
}

in a gradual increase of $\mathrm{Na}^{+}$and $\mathrm{Cl}^{-}$within the root environment (Shannon \& Grieve, 1999). Throughout the world, about one billion hectares of land are salt-affected (including both saline and sodic soils), corresponding to more than $6 \%$ of the world's total land area, while in European Union an estimated one million hectares, mainly located within the Mediterranean basin, are affected by high salinity (FAO, 2009). Plants grown in such soils are subjected to morphological, physiological and metabolical changes which cause stomatal closure and reduced photosynthetic rate, followed by lower plant growth and development and consequently by significant yield and quality loses (Arshi, Abdin, \& Iqbal, 2006; Chartzoulakis, 1994).

Most of the cultivated species are sensitive to saline conditions (e.g. beans, onion, carrot); however there are species considered 
tolerant (e.g. tomato, cabbage, broccoli) or even resistant (asparagus, root-beet, spinach) to moderate salinity without significant effects on plant growth, yield (Shannon \& Grieve, 1999) and quality (De Pascale \& Barbieri, 1995). Wild greens are being used in human diet for many centuries and several studies have confirmed their high nutritional value and antioxidant activity (Morales et al., 2012; Pereira, Barros, Carvahlo, \& Ferreira, 2011). In addition, many reports have demonstrated that high consumption of foods rich in compounds with antioxidant activity, including vitamins, phenolic acids and flavonoids, has a beneficial effect on human health and could minimize the risk of various diseases that plague the modern world, such as cancer, heart diseases etc. (Justesen \& Knuthsen, 2001).

Cichorium spinosum L., also known in Greek language as "stamnagathi", is a native plant of the Mediterranean basin, which abounds in the coastal areas of the mainland and Greek islands, especially in Crete where it is well known for centuries and being used as a vital component of the so-called Mediterranean diet (Melliou, Magiatis, \& Skaltsounis, 2003). The chemical composition of the species has been already presented by Vardavas, Majchrzak, Wagner, Elmadfa, and Kafatos (2006) regarding the content of leaf tissues in vitamins (K1 and $\mathrm{C}$ ), lutein and $\beta$-carotene, and tocopherols ( $\alpha-, \gamma$ - and total tocopherols), while Zeghichi, Kallithraka, and Simopoulos (2003) have determined ascorbic acid, vitamin C, $\beta$-carotene, tocopherols, total glutathione, phenols and proteins, antioxidant activity and minerals and fatty acids content, during the various growth stages of $C$. spinosum plants.

The fact that the species usually grows in coastal areas suggests a tolerance potential to high salinity and harsh conditions due to sea water intrusion in groundwater deposits (Chartzoulakis \& Klapaki, 2000). Although salinity has been reported to affect development and growth of other cultivated Cichorium species (e.g. endive) (Arshi, Ahmad, Aref, \& Iqbal, 2010; Tzortzakis, 2009), wild chicory (Cichorium intybus) has been described as tolerant under mild saline conditions $(100 \mathrm{mM} \mathrm{NaCl}$ ) (Sergio et al., 2014). So far, scarce literature is known regarding the effect of salinity on Cichorium spinosum, despite the fact that Greek farmers have started to commercially cultivate the species during the last few years with very promising results. Recently, Klados and Tzortzakis (2014), examined the effect of high salinity and growth substrate on growth and quality of hydroponically grown C. spinosum plants and reported that high salinity $(120 \mathrm{mM} \mathrm{NaCl})$ reduced significantly plant fresh weight and total protein content, and increased total phenolics content, bitterness and sourness of leaves.

A possible means to overcome the problems of high salinity of agricultural land is to cultivate tolerant plant species that can withstand high concentration of $\mathrm{NaCl}$ in soil and irrigation water without compromising the yield and quality of the final product (Ksouri et al., 2011; Ventura \& Sagi, 2013). Species that have already been proposed as potential candidates for such purposes are Crithmum maritimum, Salicornia europea and Lepidium latifolium (Atia, Barhoumi, Mokded, Abdelly, \& Smaoui, 2011; Ushakova, Kovaleva, Gribovskaya, Dolgushev, \& Tikhomirova, 2005; Ventura \& Sagi, 2013). Coastal and semi-arid areas, as well as areas where groundwater quality has been degraded due to irrational use of fertilizers could be the best candidates for cultivation of these species, since most of the conventional crops cannot be cultivated under such conditions or the yield losses affect severely trading profit.

Although yield loss is an important agronomic feature for commercial crop cultivation, the nutritional value and chemical composition of the final product are also very important from the consumers' point of view. In this context, the aim of the present study was to cultivate Cichorium spinosum plants under three salinity levels $(2,4$ and $8 \mathrm{dS} / \mathrm{m})$ in order to examine the effect of high salinity on nutritional profile, chemical composition, antioxidant activity and bioactive compounds content, and evaluate the effect of such conditions on the quality of the final product.

\section{Materials and methods}

\subsection{Plant material}

The present study was conducted at the experimental farm of the University of Thessaly throughout the growing period of 2014-2015 (autumn to early spring) in an unheated plastic greenhouse. Seeds of Cichorium spinosum L. were put in seed trays on October 10th, 2014 containing peat, and transplanted at the stage of 3 leaves (56 days after sowing) on December 5th, 2014 in 2 L pots containing peat (Klassman-Deilmann KTS2) and perlite in a ratio of $2: 1(\mathrm{v} / \mathrm{v})$. After transplanting, plants were fertilized via the irrigation water with $20-20-20$ fertilizer (N-P-K) by adding $150-200 \mathrm{ml}$ of nutrient solution (1.2 $\mathrm{g}$ of fertilizer per liter of water); from then on all plants were treated with Control solution until salinity treatment initiation. Treatment solutions were as follows: Control $\left(1.8 \mathrm{dS} \mathrm{m}^{-1}\right.$, no $\mathrm{NaCl}$ added $), \mathrm{S}_{1}\left(4 \mathrm{dS} \mathrm{m}^{-1}\right), \mathrm{S}_{2}$ $\left(6 \mathrm{dS} \mathrm{m}^{-1}\right)$ and $\mathrm{S}_{3}\left(8 \mathrm{dS} \mathrm{m}^{-1}\right)$. Control $(\mathrm{C})$ was prepared by adding 20-20-20 and $\mathrm{NH}_{4} \mathrm{NO}_{3}$ fertilizers in order to obtain a nutrient solution with $300 \mathrm{ppm}$ of $\mathrm{NO}_{3}^{-}$. The saline solutions $\left(\mathrm{S}_{1}-\mathrm{S}_{3}\right)$ were prepared by adding $\mathrm{NaCl}$ in the nutrient solution in order to obtain the target EC values. Saline solutions were applied after plants were fully established (on January 15th, 2015) and treatments continued until harvest (147 days after sowing). Plants were harvested on March 6th, 2015, as soon as they reached marketable size.

\subsection{Chemical composition analyses}

For chemical composition, raw samples of leaves were stored at deep freezing conditions $\left(-80^{\circ} \mathrm{C}\right)$ and freeze-dried prior to analysis.

For the macronutrient analysis, proteins, fat, carbohydrates and ash were determined using standard analytical methods described by AOAC procedures (AOAC, 2005). Nitrogen content (N) was determined using the macro-Kjeldahl method, according to AOAC procedure 978.04 (AOAC, 2005), the protein content was calculated as $\mathrm{N} \times 6.25$. Crude fat was determined using a Soxhlet apparatus with petroleum ether, following AOAC 920.85 methodology (AOAC, 2005). Ash content was determined by incineration at $600{ }^{\circ} \mathrm{C}$ until a constant mass weight was achieved according to the AOAC procedures 923.03 (AOAC, 2005). Total carbohydrates were calculated by difference and energy was calculated following the equation: Energy $(\mathrm{kcal})=4 \times(\mathrm{g}$ protein $)+4 \times(\mathrm{g}$ carbohydrate $)+9 \times(\mathrm{g}$ fat $)$.

For the mineral composition, samples of leaves tissues were dried in a forced-air oven at $72{ }^{\circ} \mathrm{C}$ to constant weight, ground to powder, subjected to dry ashing and extracted with $1 \mathrm{~N} \mathrm{HCl}$ to determine the mineral content. $\mathrm{Ca}, \mathrm{Mg}, \mathrm{Fe}, \mathrm{Mn}, \mathrm{Zn}$, and $\mathrm{Cu}$ content were determined by atomic absorption spectrophotometry (Perkin Elmer 1100B, Waltham, MA) and $\mathrm{Na}$ and $\mathrm{K}$ content by flame photometry (Sherwood Model 410, Cambridge, UK).

Free sugars were performed by high performance liquid chromatography with a refraction index detector (HPLC-RI; Knauer, Smartline system 1000, Berlin, Germany), as previously described by the authors Guimarães et al. (2013). The chromatographic separation was achieved using an equipped with a quaternary pump (Knauer, Smartline system 1000, Berlin, Germany), degasser (Smartline manager 5000), auto sampler (AS-2057 Jasco, Easton, MD, USA), an RI detector (Knauer Smartline 2300, Berlin, Germany) and the HPLC system was controlled by Clarity 2.4 Software (DataApex, Podohradska, Czech Republic). The sugars were identified by comparing their retention times with standard compounds 
and quantification was conducted by comparison with doseresponse curves constructed from authentic standards, using the internal standard (IS, melezitose) method.

Ascorbic acid was determined following a procedure previously described by the authors (Pereira, Barros, Carvalho, \& Ferreira, 2013). The chromatographic separation was achieved using a Shimadzu 20A series UFLC (Shimadzu Cooperation, Kyoto, Japan), with a degasser, auto sampler, quaternary pump and diode array detector (DAD). Samples were scanned between 200 and $800 \mathrm{~nm}$ and the detection wavelength used was $245 \mathrm{~nm}$. Quantitative analysis of ascorbic acid was performed by comparison with dose-response curves constructed on the UV signal of the authentic standards.

Fatty acids were analyzed with a DANI 1000 gas chromatographer (GC) coupled to a flame ionization detector (FID), after a transesterification procedure described by Guimarães et al. (2013). The FAMEs were identified by comparing their retention time with authentic standards and the results were recorded and processed using Clarity 4.0.1.7 Software (DataApex, Podohradska, Czech Republic).

Tocopherols were determined following a procedure previously described by the authors (Guimarães et al., 2013). The chromatographic separation was achieved using the HPLC equipment described above for free sugars, with a fluorescence detector (FP-2020; Jasco), programmed for excitation at $290 \mathrm{~nm}$ and emission at $330 \mathrm{~nm}$. The compounds were identified by chromatographic comparisons with authentic standards. Tocopherols were identified by comparing their retention times with standard compounds and quantification was conducted by comparison with dose-response curves constructed from authentic standards, using the IS (tocol) method.

Chlorophylls a and b were analysed in a fine dried powder $(150 \mathrm{mg})$ by dynamically shaking a mixture of acetone/hexane $(4: 6 ; 10 \mathrm{~mL})$ for $1 \mathrm{~min}$. Afterwards, the sample was filtered through a Whatman No. 4 filter paper. The filtrate absorbance was measured at 453, 505, 645 and $663 \mathrm{~nm}$ in a spectrophotometer (AnalytikJena, Jena, Germany). Contents were calculated according to the following equations: Chlorophyll a $(\mathrm{mg} / 100 \mathrm{ml})=0.999 \times$ $\mathrm{A}_{663}-0.0989 \times \mathrm{A}_{645}$; Chlorophyll $\mathrm{b}(\mathrm{mg} / 100 \mathrm{ml})=-0.328 \times \mathrm{A}_{663}+$ $1.77 \times \mathrm{A}_{645}$ (Nagata \& Yamashita, 1992).

\subsection{Phenolic compounds analysis and antioxidant activity assays}

In order to obtain the methanolic/water $(80: 20, v / v)$ extracts, one gram of each lyophilized material was extracted twice for $1 \mathrm{~h}$ in a magnetic stirrer plate $\left(25^{\circ} \mathrm{C}\right.$ at $\left.150 \mathrm{rpm}\right)$, with $30 \mathrm{~mL}$ of methanol/water $(80: 20, v / v)$, filtered through a Whatman No. 4 paper and vacuum-dried in a rotary evaporator (rotary evaporator Büchi R-210, Flawil, Switzerland) at $40{ }^{\circ} \mathrm{C}$ to remove the methanol. The extract was further frozen and lyophilized. The extracts were redissolved in methanol/water $(80: 20, v / v)$ at a final concentration of $50 \mathrm{mg} / \mathrm{mL}$ and further diluted to different concentrations to be submitted to the distinct in vitro antioxidant activity assays, and $1 \mathrm{~mL}$ of the extract $(5 \mathrm{mg} / \mathrm{mL})$ was filtered through a $0.45 \mu \mathrm{m}$ Whatman syringe filter, transferred to amber color HPLC vial for phenolic compound analysis.

For phenolic compounds, LC-DAD-ESI/MSn analyses were performed using a Dionex Ultimate 3000 UPLC instrument (Thermo Scientific, San Jose, CA, USA) equipped with a diodearray detector and coupled to a mass detector. The chromatographic system consisted of a quaternary pump, an autosampler maintained at $5^{\circ} \mathrm{C}$, a degasser, a photodiode-array detector and an automatic thermostatic column compartment. The chromatographic separation was carried out on a Waters Spherisorb S3 ODS-2 C18, ( $3 \mu \mathrm{m}, 4.6 \mathrm{~mm} \times 150 \mathrm{~mm}$, Waters, Milford, MA, USA) column thermostatted at $35^{\circ} \mathrm{C}$. The solvents used were: (A) $0.1 \%$ formic acid in water, (B) acetonitrile. Gradient elution was carried out using the following timetable: $15 \%$ for $5 \mathrm{~min}, 15 \% \mathrm{~B}$ to $20 \% \mathrm{~B}$ over $5 \mathrm{~min}, 20-25 \%$ B over $10 \mathrm{~min}, 25-35 \%$ B over $10 \mathrm{~min}$, $35-50 \%$ B for $10 \mathrm{~min}$. The resulting total run time was $55 \mathrm{~min}$, followed by column reconditioning of $10 \mathrm{~min}$, using a flow rate of $0.5 \mathrm{~mL} / \mathrm{min}$. The chromatogram was recorded at several wavelengths, characteristic of different classes of polyphenols, such as $280 \mathrm{~nm}$ for phenolic acids, $330 \mathrm{~nm}$ for hydroxycinnamic acids, $370 \mathrm{~nm}$ for flavonols, and $520 \mathrm{~nm}$ for anthocyanins.

The mass spectrometer was operated in negative ion mode using Linear Ion Trap LTQ XL mass spectrometer (ThermoFinnigan, San Jose, CA, USA) equipped with an ESI source. Typical ESI conditions were nitrogen sheath gas 50 psi, spray voltage $5 \mathrm{kV}$, source temperature $325^{\circ} \mathrm{C}$, capillary voltage $-20 \mathrm{~V}$, and the tube lens offset was kept at voltage of $-66 \mathrm{~V}$. The full scan covered the mass range from $\mathrm{m} / \mathrm{z} 100$ to 1500 . The collision energy used was 35 (arbitrary units). Data acquisition was carried out with Xcalibur $\left.^{(}\right)$data system (ThermoFinnigan, San Jose, CA, USA).

Identification of the phenolic compounds was performed by comparing their fragmentation pattern, retention times, UV-vis spectra with authentic standards, when available, or by comparing the obtained information with available data from literature. Quantitative analysis was obtained using calibration curves for each of the available phenolic standard: caffeic acid $(y=359 x+$ 488; $\left.R^{2}=0.998\right) ; \quad$ chlorogenic acid $\left(\mathrm{y}=304 \mathrm{x}-248 ; \quad R^{2}=1\right)$ $p$-coumaric $\left(\mathrm{y}=706 \mathrm{x}+1228 ; R^{2}=0.999\right)$; ferulic acid $(\mathrm{y}=525 \mathrm{x}+$ 234; $\left.R^{2}=0.999\right)$; kaempferol-3-0-glucoside $\left(\mathrm{y}=236 \mathrm{x}+70 ; R^{2}=1\right)$; kaempferol-3-O-rutinoside ( $\left.\mathrm{y}=183 \mathrm{x}+97 ; R^{2}=1\right)$; quercetin-3-Oglucoside $\left(\mathrm{y}=336 \mathrm{x}+358 ; R^{2}=0.998\right)$ and quercetin-3-O-rutinoside $\left(\mathrm{y}=281 \mathrm{x}+374 ; R^{2}=0.998\right)$. When a standard is not available to quantify a phenolic compound a calibration curve of another compound from the same phenolic group was used.

DPPH radical-scavenging activity was assessed using an ELX800 microplate reader (Bio-Tek Instruments, Inc; Winooski, VT, USA) at $515 \mathrm{~nm}$. The percentage of DPPH discolouration was calculated using the following equation: $\left[\left(A_{D P P H}-A_{S}\right) / A_{D P P H}\right] \times 100$, where $A_{S}$ is the absorbance of the solution containing the sample and $A_{D P P H}$ is the absorbance of the DPPH solution. Reducing power was determined in the microplate reader mentioned above using an absorbance at $690 \mathrm{~nm}$. This methodology measures the capacity of the extract to convert $\mathrm{Fe}^{3+}$ to $\mathrm{Fe}^{2+}$. $\beta$-Carotene bleaching inhibition was assessed though the $\beta$-carotene/linoleate assay measured at $470 \mathrm{~nm}$, and determined using the following equation: ( $\beta$-carotene absorbance after $2 \mathrm{~h}$ of assay/initial absorbance) $\times$ 100. Lipid peroxidation inhibition (LPI) in porcine brain homogenates was assessed by measuring the decreasing in thiobarbituric acid reactive substances (TBARS) at the absorbance of $532 \mathrm{~nm}$. LPI (\%) was calculated using the following equation: $[(A-B) / A] \times$ $100 \%$, where $A$ and $B$ were the absorbance of the control and the sample solution, respectively. Trolox was used as a positive control and $\mathrm{EC}_{50}$ values (sample concentration providing $50 \%$ of antioxidant activity or 0.5 of absorbance in the reducing power assay) were used to expressed the results for antioxidant activity (Guimarães et al., 2013).

\subsection{Statistical analysis}

For nutritional and chemical composition analyses, three samples were analysed for each treatment, while all the assays were carried out in triplicate. The results were expressed as mean values and standard deviations (SD), and analyzed using one-way analysis of variance (ANOVA) followed by Tukey's HSD Test with $\alpha=0.05$. This analysis was carried out using SPSS v. 22.0 program (IBM Corp., Armonk, NY, USA). 


\section{Results and discussion}

\subsection{Effect of salinity on chemical composition}

Nutritional value of Cichorium spinosum is presented in Table 1. Similarly to most leafy vegetables, $C$. spinosum leaves have high water content and are of high nutritional value with low energy and high protein content. Dry matter content (\%) had the highest value at moderate salinity levels $\left(6.0 \mathrm{dS} \mathrm{m}^{-1}\right)$, while fat and carbohydrates contents were significantly higher in control treatment comparing to salinity levels. In contrast, protein and ash content were higher at the highest and mid-to-high salinity level (8.0 and $6.0 \mathrm{dS} \mathrm{m}^{-1}$, respectively), than control and low salinity treatment. Regarding energy balance, both control and mid-to-high treatments had significantly higher values than the other treatments, although these differences do not have a significant impact on energy contribution in human body, considering the low amounts consumed on a daily basis diet.

Klados and Tzortzakis (2014) have also reported an increasing trend for dry matter content, when salinity level of nutrient solution increased; however this trend was observed only when growth substrate was perlite or pumice and not for rockwool or sand. In contrast with the present study, the same authors reported that protein content decreased significantly when medium salinity was $120 \mathrm{mM} \mathrm{NaCl}$. The fact that in this study the plants were grown hydroponically and in different substrates could explain the different results comparing to our study. In addition, the higher dry matter contents (12.6-19.3\%) comparing to those of our study indicate more stressful conditions that could severely affect nutritional value. Regarding protein content, in our study it was about three to four times higher than that reported by Zeghichi et al. (2003) (maximum content of $358.6 \mathrm{mg} 100 \mathrm{~g}^{-1}$ f.w.), a difference that could be attributed to the fact that no fertilizers were applied during the growing season in this study, as well as to the different growing medium, that both could affect plant metabolism and consequently protein biosynthesis.

Sugar content consisted mostly of glucose and to a lesser degree of sucrose and fructose (Table 1 ). In addition, saline conditions resulted in a gradual decrease of individual sugars and consequently of the total sugar content. However, a lower decrease rate for sucrose was observed in the highest salinity level, comparing to fructose and glucose decrease rate, which consequently results in a higher sucrose: glucose and sucrose: fructose ratio. This change in sugar composition could affect organoleptic properties and taste. To our knowledge, this is the first time that total sugar content and sugar composition of $C$. spinosum leaves is reported. Klados and Tzortzakis (2014) conducted a panel test for quality assessment and reported that high salinity resulted in an increase of bitterness and sourness of leaves that could be associated with changes in sugar composition and total sugar content, without however to proceed with sugars and carbohydrate content determination.

Ascorbic acid content was also affected by salinity, as presented in Table 1. Although mid-to-high salinity levels $\left(6.0 \mathrm{dS} \mathrm{m}^{-1}\right)$ had a beneficial effect on ascorbic acid content, a further increase of nutrient solution salinity $\left(8.0 \mathrm{dS} \mathrm{m}^{-1}\right)$ resulted in a severe decrease (35\%) of ascorbic acid. To our knowledge, the effect of salinity on ascorbic acid content of $C$. spinosum leaves has not been reported so far. Vardavas et al. (2006) and Zeghichi et al. (2003) have previously determined the ascorbic acid content and reported significantly higher values comparing to those in our study $(27 \mathrm{mg}$ $100 \mathrm{~g}^{-1}$ f.w. and $17.58-36.58 \mathrm{mg} 100$ wet weight, respectively). However these differences could be attributed not only to different determination assays, since chromatographic analyses are more precise than colorimetric assays, but also to different growing conditions, since in the first study samples were collected from wild ecotypes located either in Crete island midlands or in high altitudes, while in the second study plants were grown in a different substrate and without application of fertilizers. According to Mozafar (1993), nitrogen fertilizer application above the plant nutrient requirements could result in a significant decrease of ascorbic acid content. Therefore, further studies are needed in order to define the nutrient requirements of $C$. spinosum and increase yield without compromising quality.

The fatty acids composition of $C$. spinosum leaves is presented in Table 2 . The most abundant fatty acids, regardless of treatment, were $\alpha$-linolenic acid (C18:3n3; ALA) which ranged from 53.02 to 55.34\%, linoleic acid (C18:2n6; LA) which ranged from 25.09 to 26.28\%, and palmitic acid (C16:0; PA) which ranged from 10.34 to $12.24 \%$, while stearic acid (C18:0; SA), oleic acid (C18:1n9; $\mathrm{OA}$ ) and lignoceric acid (C24:0) were detected in relatively lower amounts. Moreover, salinity treatments did not significantly affect the main fatty acids content and only slight fluctuations were observed. For all the treatments there was an abundance of PUFA (>78\%), mainly consisting of ALA and LA. Moreover, fatty acids composition depicted the high nutritional value of $C$. spinosum leaves, since PUFA/SFA ratio was higher than 0.45 (4.35-4.99) and n-6/n-3 ratio lower than $4.0(0.45-0.48)$, which both are considered as significant indices for quality and health benefits (Guil, Torija, Giménez, \& Rodriguez, 1996). According to Simopoulos (2008), diets with low $n-6 / n-3$ ratio may reduce the risk of many chronic diseases that plague the modern Western world, and the adoption of Mediterranean diet would be beneficial to that purpose. Although $C$. spinosum leaves have a considerable low n-6/n3 ratio, high salinity treatment resulted in a further decrease for this ratio which could be very important from nutritional point of view, considering the high intake of n-6 fatty acids on a daily

Table 1

Macronutrients, free sugars and ascorbic acid of Cichorium spinosum leaves (mean \pm SD).

\begin{tabular}{|c|c|c|c|c|}
\hline Macronutrients & Control & $4 \mathrm{dS} \mathrm{m}^{-1}$ & $6 \mathrm{dS} \mathrm{m}^{-1}$ & $8 \mathrm{dS} \mathrm{m}^{-1}$ \\
\hline Moisture (g/100 g fw) & $91.70 \pm 1.6 \mathrm{ab}$ & $92.81 \pm 1.2 \mathrm{a}$ & $91.48 \pm 1.0 \mathrm{~b}$ & $92.01 \pm 0.7 \mathrm{a}$ \\
\hline Fat $(g / 100 \mathrm{~g} \mathrm{fw})$ & $0.28 \pm 0.01 a$ & $0.24 \pm 0.01 \mathrm{~b}$ & $0.22 \pm 0.01 c$ & $0.22 \pm 0.02 c$ \\
\hline Proteins (g/100 g fw) & $1.11 \pm 0.10 b$ & $1.23 \pm 0.04 b$ & $1.41 \pm 0.08 a$ & $1.43 \pm 0.10 a$ \\
\hline Ash (g/100 g fw) & $1.01 \pm 0.01 \mathrm{c}$ & $0.96 \pm 0.01 d$ & $1.28 \pm 0.01 \mathrm{a}$ & $1.14 \pm 0.01 b$ \\
\hline Carbohydrates (g/100 g fw) & $5.90 \pm 0.07 a$ & $4.76 \pm 0.02 d$ & $5.61 \pm 0.06 b$ & $5.20 \pm 0.08 c$ \\
\hline Energy (kcal/100 g fw) & $30.55 \pm 0.03 a$ & $26.16 \pm 0.04 c$ & $30.06 \pm 0.04 a$ & $28.50 \pm 0.07 b$ \\
\hline \multicolumn{5}{|l|}{ Free sugars } \\
\hline Fructose $(\mathrm{g} / 100 \mathrm{~g} \mathrm{fw}$ & $0.51 \pm 0.01 \mathrm{a}$ & $0.28 \pm 0.01 \mathrm{c}$ & $0.39 \pm 0.01 b$ & $0.28 \pm 0.01 \mathrm{c}$ \\
\hline Glucose $(\mathrm{g} / 100 \mathrm{~g}$ fw & $0.69 \pm 0.01 \mathrm{a}$ & $0.43 \pm 0.01 \mathrm{c}$ & $0.63 \pm 0.01 b$ & $0.45 \pm 0.01 c$ \\
\hline Sucrose $(\mathrm{g} / 100 \mathrm{~g}$ fw & $0.50 \pm 0.01 \mathrm{a}$ & $0.39 \pm 0.01 d$ & $0.46 \pm 0.01 b$ & $0.42 \pm 0.02 c$ \\
\hline Sum $(g / 100 \mathrm{~g} \mathrm{fw})$ & $1.70 \pm 0.01 \mathrm{a}$ & $1.10 \pm 0.02 \mathrm{c}$ & $1.48 \pm 0.03 b$ & $1.15 \pm 0.04 c$ \\
\hline Ascorbic acid (mg/100 g fw) & $2.79 \pm 0.01 b$ & $2.01 \pm 0.11 \mathrm{c}$ & $3.28 \pm 0.07 a$ & $2.11 \pm 0.06 c$ \\
\hline
\end{tabular}

In each row different letters mean significant differences between samples $(p<0.05)$. 
Table 2

Composition of fatty acids, tocopherols and chlorophylls of Cichorium spinosum leaves (mean $\pm \mathrm{SD})$.

\begin{tabular}{|c|c|c|c|c|}
\hline & Control & $4 \mathrm{dS} \mathrm{m}^{-1}$ & $6 \mathrm{dS} \mathrm{m}^{-1}$ & $8 \mathrm{dS} \mathrm{m}^{-1}$ \\
\hline \multicolumn{5}{|l|}{ Fatty acids } \\
\hline C6:0 & $0.01 \pm 0.01$ & $0.04 \pm 0.01$ & $0.02 \pm 0.01$ & $0.03 \pm 0.01$ \\
\hline C8:0 & $0.02 \pm 0.01$ & $0.04 \pm 0.01$ & $0.03 \pm 0.01$ & $0.04 \pm 0.01$ \\
\hline C10:0 & $0.04 \pm 0.01$ & $0.08 \pm 0.01$ & $0.05 \pm 0.01$ & $0.08 \pm 0.01$ \\
\hline C12:0 & $0.04 \pm 0.01$ & $0.09 \pm 0.01$ & $0.06 \pm 0.01$ & $0.10 \pm 0.01$ \\
\hline $\mathrm{C} 14: 0$ & $0.21 \pm 0.02$ & $0.28 \pm 0.02$ & $0.36 \pm 0.02$ & $0.31 \pm 0.01$ \\
\hline C15:0 & $0.30 \pm 0.01$ & $0.37 \pm 0.01$ & $0.34 \pm 0.01$ & $0.34 \pm 0.01$ \\
\hline C16:0 & $10.34 \pm 0.38$ & $11.02 \pm 0.27$ & $12.24 \pm 0.04$ & $11.23 \pm 0.06$ \\
\hline C16:1 & $0.25 \pm 0.01$ & $0.31 \pm 0.01$ & $0.24 \pm 0.01$ & $0.26 \pm 0.01$ \\
\hline C17:0 & $0.15 \pm 0.01$ & $0.18 \pm 0.01$ & $0.20 \pm 0.01$ & $0.19 \pm 0.01$ \\
\hline C18:0 & $1.13 \pm 0.01$ & $1.66 \pm 0.03$ & $1.75 \pm 0.05$ & $1.50 \pm 0.01$ \\
\hline C18:1n9 & $1.81 \pm 0.02$ & $2.16 \pm 0.02$ & $2.85 \pm 0.05$ & $2.07 \pm 0.02$ \\
\hline C18:2n6 & $26.28 \pm 0.07$ & $25.10 \pm 0.03$ & $25.25 \pm 0.09$ & $25.09 \pm 0.07$ \\
\hline$C 18: 3 n 3$ & $54.70 \pm 0.13$ & $54.62 \pm 0.04$ & $53.02 \pm 0.26$ & $55.34 \pm 0.09$ \\
\hline C20:0 & $0.40 \pm 0.03$ & $0.44 \pm 0.02$ & $0.39 \pm 0.03$ & $0.40 \pm 0.01$ \\
\hline C20:1 & $0.22 \pm 0.02$ & $0.13 \pm 0.01$ & $0.24 \pm 0.02$ & $0.17 \pm 0.01$ \\
\hline C20:2 & $0.20 \pm 0.01$ & $0.18 \pm 0.01$ & $0.17 \pm 0.01$ & $0.15 \pm 0.01$ \\
\hline$C 20: 3 n 3$ & $0.21 \pm 0.01$ & $0.27 \pm 0.01$ & $0.19 \pm 0.01$ & $0.22 \pm 0.01$ \\
\hline $\mathrm{C} 21: 0$ & $0.06 \pm 0.01$ & $0.08 \pm 0.01$ & $0.06 \pm 0.01$ & $0.07 \pm 0.01$ \\
\hline$C 20: 5 n 3$ & $0.01 \pm 0.01$ & $0.02 \pm 0.01$ & $0.01 \pm 0.01$ & $0.04 \pm 0.01$ \\
\hline $\mathrm{C} 22: 0$ & $0.82 \pm 0.04$ & $0.76 \pm 0.04$ & $0.65 \pm 0.03$ & $0.61 \pm 0.02$ \\
\hline C23:0 & $0.28 \pm 0.02$ & $0.26 \pm 0.01$ & $0.25 \pm 0.01$ & $0.25 \pm 0.02$ \\
\hline $\mathrm{C} 24: 0$ & $2.49 \pm 0.08$ & $1.92 \pm 0.13$ & $1.64 \pm 0.11$ & $1.50 \pm 0.05$ \\
\hline $\begin{array}{l}\text { Total SFA } \\
\quad(\% \text { of total FA) }\end{array}$ & $16.32 \pm 0.23 c$ & $17.21 \pm 0.09 b$ & $18.04 \pm 0.27 a$ & $16.66 \pm 0.17 c$ \\
\hline $\begin{array}{l}\text { Total MUFA } \\
\quad(\% \text { of total FA) }\end{array}$ & $2.28 \pm 0.03 d$ & $2.60 \pm 0.01 b$ & $3.34 \pm 0.08 a$ & $2.51 \pm 0.01 c$ \\
\hline $\begin{array}{l}\text { Total PUFA } \\
\quad(\% \text { of total FA) }\end{array}$ & $81.40 \pm 0.21 a$ & $80.19 \pm 0.08 b$ & $78.63 \pm 0.35 c$ & $80.84 \pm 0.18 b$ \\
\hline \multicolumn{5}{|l|}{ Tocopherols } \\
\hline$\alpha$-Tocopherol & $1.13 \pm 0.03 b$ & $1.12 \pm 0.03 b$ & $1.39 \pm 0.02 a$ & $0.79 \pm 0.02 c$ \\
\hline$\delta$-Tocopherol & $1.05 \pm 0.02 a$ & $0.66 \pm 0.03 c$ & $0.83 \pm 0.01 b$ & $0.81 \pm 0.03 b$ \\
\hline $\begin{array}{l}\text { Sum tocopherols } \\
\quad(\mathrm{mg} / 100 \mathrm{~g} \mathrm{fw})\end{array}$ & $2.18 \pm 0.05 a$ & $1.78 \pm 0.05 b$ & $2.22 \pm 0.03 a$ & $1.60 \pm 0.01 c$ \\
\hline \multicolumn{5}{|l|}{ Chlorophyll } \\
\hline $\begin{array}{l}\text { Chlorophyll a } \\
\qquad(\mu \mathrm{g} / 100 \mathrm{~g} \mathrm{fw})\end{array}$ & $110.8 \pm 0.1 \mathrm{a}$ & $92.7 \pm 0.4 d$ & $99.7 \pm 0.1 \mathrm{c}$ & $102.0 \pm 0.2 b$ \\
\hline $\begin{array}{l}\text { Chlorophyll b } \\
\qquad(\mu \mathrm{g} / 100 \mathrm{~g} \mathrm{fw})\end{array}$ & $32.4 \pm 0.1 \mathrm{a}$ & $26.6 \pm 0.3 c$ & $30.9 \pm 0.1 b$ & $30.5 \pm 0.1 b$ \\
\hline
\end{tabular}

In each row different letters mean significant differences between samples $(\mathrm{p}<0.05)$.

basis and the relatively low variety of n-3 rich foods in modern diets.

Regarding tocopherol content, medium to high salinity levels $\left(6 \mathrm{dS} \mathrm{m}^{-1}\right.$ ) resulted in higher content of $\alpha$-tocopherol, comparing to control and low and high salinity levels, whereas a further increase of salinity $\left(8 \mathrm{dS} \mathrm{m}^{-1}\right)$ had a negative effect on tocopherol content (Table 2 ). In contrast, $\delta$-tocopherol was negatively affected by salinity regardless of the treatment level. Total tocopherols content of control and medium salinity treatment did not differ significantly and saline conditions favoured $\alpha$-tocopherol biosynthesis over $\delta$-tocopherol. Moreover, total tocopherols content decreased significantly at the highest salinity level, a result that comes in agreement with those of Yusuf et al. (2010), who also reported a decrease of total tocopherols with increasing salinity, mostly due to $\alpha$-tocopherol decrease. The effect of salinity on tocopherol content has been confirmed by Lushchak and Semchuk (2012) who reported that salinity stress induces the production of antioxidants, such as tocopherols, which act as protection agents against reactive oxygen species (ROS), while tocopherols content is highly correlated with stress level, growth stage and even species or cultivar tolerance (Munne-Bosch, 2005). Similar amounts of $\alpha$-tocopherol in $C$. spinosum have been reported by Vardavas et al. (2006), although they also detected $\gamma$-tocopherol which was not the case in our study. Moreover, Tarchoune et al. (2013) reported that tocopherol biosynthesis under stressful conditions is involved in mechanisms responsible for the detoxification of ROS in mildly salt tolerant species such as basil.

Chlorophyll content (both chlorophyll a and b) were significantly decreased with increasing salinity, a result that has to be correlated with the decrease of $\alpha$-tocopherol content which was also observed in the present study (Table 2). According to Camara, Bardat, Seye, D'Harlinge, and Moneger (1982), $\alpha$-tocopherol and chlorophyll are both located in chloroplasts and $\alpha$-tocopherol acts as protecting agent of chlorophyll, therefore chlorophyll loss could be the result of $\alpha$-tocopherol decrease and consequently the inactivation of the involved protection mechanisms.

Regarding mineral composition, $C$. spinosum leaves are a rich source of macro and micro-nutrients, as presented in Table 3. Although salinity increase resulted in a decrease of $\mathrm{K}$ content, the rest of the nutrients were beneficially affected by saline conditions and a significant increase of their content was detected. Moreover, a significant increase was observed for the ratios of $\mathrm{Na} / \mathrm{K}, \mathrm{Na} / \mathrm{Ca}$ and $\mathrm{Na} / \mathrm{Mg}$ with increasing salinity, which confirms the halophytic nature of the species (Yousif et al., 2010). Special mention must be made of high Na content which could have adverse health effects, especially for individuals who are in a low Na uptake diet, since the detected values were considerably higher comparing to those reported by Zeghichi et al. (2003). The high content of $\mathrm{Na}$ in this study should be attributed to fertilizer application and salinity treatments, and it could be suggested that the species uses $\mathrm{Na}$ accumulation as a means to alleviate adverse effects of salinity. For the rest of the minerals, Mn content was significantly lower in our study comparing to the results of Zeghichi et al. (2003), K and $\mathrm{Fe}$ were significantly higher and $\mathrm{Ca}, \mathrm{Mg}$ and $\mathrm{Zn}$ within the same range of the results of that study.

\subsection{Effect of salinity on phenolic compounds and antioxidant activity}

Data of retention time, $\lambda_{\max }$, pseudomolecular ion, main fragment ions in $\mathrm{MS}^{2}$, and tentative compound identification for phenolic compounds are presented in Table 4. The phenolic composition of $C$. spinosum was characterized by the presence of eleven phenolic compounds, six phenolic acids and five compounds that corresponded to flavonoid derivatives.

Compounds $1\left([\mathrm{M}-\mathrm{H}]^{-}\right.$at $\left.m / z 311\right), 3\left([\mathrm{M}-\mathrm{H}]^{-}\right.$at $\left.m / z 473\right), 6$ $\left([\mathrm{M}-\mathrm{H}]^{-}\right.$at $\left.\mathrm{m} / \mathrm{z} 295\right)$ and $7\left([\mathrm{M}-\mathrm{H}]^{-}\right.$at $\mathrm{m} / z$ 325) presented a fragmentation pattern that allowed assigning them as caftaric, chicoric acid (dicaffeoyltartaric acid), coutaric and fertaric acids. Compound $4\left([\mathrm{M}-\mathrm{H}]^{-}\right.$at $\left.m / z 457\right)$ presented $162 \mathrm{u}$ (hexosyl moiety), higher than compound 6 and was tentatively identified as a coutaric acid

Table 3

Mineral composition of $C$. spinosum leaves expressed in mg per $100 \mathrm{~g}$ of fresh weight (mean values $\pm \mathrm{SD}$ ).

\begin{tabular}{|c|c|c|c|c|c|c|c|}
\hline Treatments & K & $\mathrm{Na}$ & $\mathrm{Ca}$ & $\mathrm{Mg}$ & $\mathrm{Mn}$ & $\mathrm{Fe}$ & $\mathrm{Zn}$ \\
\hline Control & $421.1 \pm 33.3 a$ & $98.2 \pm 6.5 d$ & $99.6 \pm 8.7 c$ & $24.2 \pm 3.7 b$ & $0.510 \pm 0.034 c$ & $0.696 \pm 0.045 b$ & $0.141 \pm 0.030 \mathrm{~b}$ \\
\hline $4 \mathrm{dS} \mathrm{m}^{-1}$ & $328.0 \pm 15.6 b$ & $139.5 \pm 4.0 c$ & $131.0 \pm 7.2 b$ & $20.4 \pm 0.8 b$ & $0.683 \pm 0.062 b$ & $0.742 \pm 0.039 b$ & $0.167 \pm 0.021 b$ \\
\hline $6 \mathrm{dS} \mathrm{m}^{-1}$ & $295.4 \pm 17.4 b$ & $172.7 \pm 15.1 b$ & $153.0 \pm 10.9 \mathrm{ab}$ & $33.4 \pm 0.8 a$ & $1.052 \pm 0.051 \mathrm{a}$ & $0.946 \pm 0.039 a$ & $0.354 \pm 0.030 a$ \\
\hline $8 \mathrm{dS} \mathrm{m}^{-1}$ & $231.0 \pm 21.8 c$ & $246.4 \pm 0.9 a$ & $168.4 \pm 15.6 a$ & $30.1 \pm 0.6 a$ & $1.144 \pm 0.077 a$ & $0.957 \pm 0.050 a$ & $0.332 \pm 0.033 a$ \\
\hline
\end{tabular}

In each column different letters mean significant differences between samples $(\mathrm{p}<0.05)$. 
Table 4

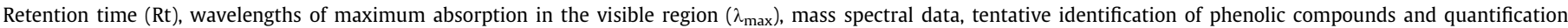
(mg/g extract) in Cichorium spinosum leaves.

\begin{tabular}{|c|c|c|c|c|c|c|c|c|c|}
\hline Compound & $\begin{array}{l}\text { Rt } \\
(\min )\end{array}$ & $\begin{array}{l}\lambda_{\max } \\
(\mathrm{nm})\end{array}$ & $\begin{array}{l}\text { Molecular ion } \\
{[\mathrm{M}-\mathrm{H}]^{-}(m / z)}\end{array}$ & $\mathrm{MS}^{2}(m / z)$ & $\begin{array}{l}\text { Tentative } \\
\text { identification }\end{array}$ & Control & $4 \mathrm{dS} \mathrm{m}^{-1}$ & $6 \mathrm{dS} \mathrm{m}^{-1}$ & $8 \mathrm{dS} \mathrm{m}^{-1}$ \\
\hline 1 & 5.1 & 328 & 311 & $179(85), 149(54), 135(100)$ & Caftaric acid & $0.84 \pm 0.03$ & $1.0 \pm 0.1$ & $1.4 \pm 0.1$ & $1.2 \pm 0.1$ \\
\hline 2 & 8.2 & 328 & 353 & $191(100), 179(71), 135(43)$ & $\begin{array}{l}\text { 5- } O \text {-Caffeoylquinic } \\
\text { acid }\end{array}$ & $3.32 \pm 0.03$ & $2.28 \pm 0.02$ & $2.45 \pm 0.02$ & $2.86 \pm 0.01$ \\
\hline 3 & 15.3 & 330 & 473 & $\begin{array}{l}313(68), 293(83), 219 \\
(13), 179(93), 149(100), \\
135(42)\end{array}$ & Chicoric acid & $16.85 \pm 0.08$ & $12.53 \pm 0.01$ & $16.44 \pm 0.03$ & $15.55 \pm 0.01$ \\
\hline 4 & 20.0 & 312 & 457 & $\begin{array}{l}295(100), 277(68), 219 \\
(26), 179(24), 163(58) \\
149(8)\end{array}$ & Coutaric acid hexoside & $0.097 \pm 0.003$ & $0.34 \pm 0.01$ & $0.45 \pm 0.01$ & $0.51 \pm 0.01$ \\
\hline 5 & 20.2 & 358 & 477 & $301(100)$ & $\begin{array}{l}\text { Quercetin-3-O- } \\
\text { glucuronide }\end{array}$ & $0.951 \pm 0.001$ & $0.745 \pm 0.001$ & $0.831 \pm 0.007$ & $1.071 \pm 0.007$ \\
\hline 6 & 21.2 & 310 & 295 & $\begin{array}{l}219(27), 179(5), 163(22) \\
149(5), 135(11)\end{array}$ & Coutaric acid & $\operatorname{tr}$ & $0.001 \pm 0.0001$ & $\operatorname{tr}$ & $0.026 \pm 0.002$ \\
\hline 7 & 21.5 & 330 & 325 & 193(100),134(98) & Fertaric acid & $0.46 \pm 0.03$ & $0.37 \pm 0.01$ & $0.62 \pm 0.03$ & $0.65 \pm 0.01$ \\
\hline 8 & 22.5 & 356 & 505 & $463(10), 301(100)$ & $\begin{array}{l}\text { Quercetin-7-O-(6"-O- } \\
\text { acetyl)-glucoside }\end{array}$ & $0.050 \pm 0.005$ & $0.007 \pm 0.001$ & $0.062 \pm 0.004$ & $0.063 \pm 0.01$ \\
\hline 9 & 23.2 & 348 & 593 & $285(100)$ & $\begin{array}{l}\text { Kaempferol-3-O- } \\
\text { rutinoside }\end{array}$ & $0.064 \pm 0.002$ & $0.067 \pm 0.001$ & $0.17 \pm 0.01$ & $0.09 \pm 0.01$ \\
\hline 10 & 24.4 & 348 & 461 & $285(100)$ & $\begin{array}{l}\text { Kaempferol-3-O- } \\
\text { glucuronide }\end{array}$ & $0.758 \pm 0.005$ & $0.551 \pm 0.001$ & $0.592 \pm 0.009$ & $0.778 \pm 0.004$ \\
\hline \multirow[t]{4}{*}{11} & 27.1 & 338 & 489 & $285(100)$ & $\begin{array}{l}\text { Kaempferol-3-O-(6"- } \\
\text { O-acetyl)-glucoside }\end{array}$ & $0.12 \pm 0.01$ & $0.088 \pm 0.002$ & $0.13 \pm 0.01$ & $0.16 \pm 0.01$ \\
\hline & & & & & Total phenolic acids & $21.6 \pm 0.3 a$ & $16.5 \pm 0.1 \mathrm{c}$ & $21.3 \pm 0.2 \mathrm{a}$ & $20.8 \pm 0.1 b$ \\
\hline & & & & & Total flavonoids & $1.94 \pm 0.01 b$ & $1.458 \pm 0.001 d$ & $1.78 \pm 0.02 c$ & $2.17 \pm 0.02 \mathrm{a}$ \\
\hline & & & & & $\begin{array}{l}\text { Total phenolic } \\
\text { compounds }\end{array}$ & $23.5 \pm 0.3 a$ & $18.0 \pm 0.1 b$ & $23.1 \pm 0.3 a$ & $23.0 \pm 0.1 \mathrm{a}$ \\
\hline
\end{tabular}

tr-traces. In each row different letters mean significant differences between samples $(\mathrm{p}<0.05)$.

hexoside. 5-O-Caffeoylquinic acid (compound 2), was positively identified according to its retention, mass spectra and UV-vis characteristics in comparison with a commercial standard. This phenolic acid, as well as compounds 1 and 3 (caftaric and chicoric acid, respectively) have been described by many authors in the leaves of C. intybus (Carazzone, Mascherpa, Gazzani, \& Papetti, 2013; Dalar \& Konczak, 2014; Heimler, Isolani, Vignolini, \& Romani, 2009; Juśkiewicz et al., 2011; Rossetto et al., 2005; Sinkovic et al., 2015), without however any studies have been carried out about $C$. spinosum phenolic compounds composition. Chicoric acid is described as one of the main phenolic acids of $C$. intybus, as also demonstrated in the present study for the relative species of C. spinosum. To our knowledge, the other compounds have not been described in $C$. intybus so far, let alone $C$. spinosum. The remaining compounds were identified as flavonoid derivatives. Compounds 5 and 8 presented pseudomolecular ions $[\mathrm{M}-\mathrm{H}]^{-}$at $\mathrm{m} / \mathrm{z} 477$ and 505 releasing a common $\mathrm{MS}^{2}$ fragment at $\mathrm{m} / \mathrm{z} 301$ $\left([\mathrm{M}-\mathrm{H}-176]^{-}\right.$and $[\mathrm{M}-\mathrm{H}-42-162]^{-}$, loss of glucuronyl and acetylhexoside moieties, respectively) and were tentatively identified as quercetin-3-O-glucuronide (compared with our library of compounds) and quercetin-O-acetylhexoside, respectively. Similarly, compounds 9,10 and 11 presented pseudomolecular ions $[\mathrm{M}-\mathrm{H}]^{-}$at $m / z 461,593$ and 489 releasing a common $\mathrm{MS}^{2}$ fragment at $\mathrm{m} / \mathrm{z} 285\left([\mathrm{M}-\mathrm{H}-176]^{-} \text {, ([M-H-308 }\right]^{-}$and $[\mathrm{M}-\mathrm{H}-42$ $-162]^{-}$, loss of glucuronyl, rutinosyl and acetylhexoside moieties, respectively) and were tentatively identified as kaempferol-3-Oglucuronide, kaempferol-3-O-rutinoside (retention time compared with a commercial standard) and kaempferol-O-acetylhexoside, respectively. Carazzone et al. (2013) identified three similar compounds in leaves samples of $C$. intybus, as quercetin-7-O-(6"$O$-acetyl)-glucoside, kaempferol-3-O-glucuronide and kaempferol3-O-(6"-O-acetyl)-glucoside, thus this assumption could be attributed to the compounds found in the present work. Overall, the most abundant phenolic acid found in all the treatments was chicoric acid, while the most abundant flavonoid was quercetin3-O-glucuronide.
The total phenolic compounds ranged from 18.0 to $23.5 \mathrm{mg} \mathrm{g}^{-1}$ extract, with no significant differences being observed between control treatment and mid-to-high and high salinity levels (6.0 and $8.0 \mathrm{dS} \mathrm{m}^{-1}$ ) (Table 4). Similarly, total phenolic acids content (mainly consisted of chicoric acid) did not differ for control treatment and mid-to-high salinity and slightly decreased in high salinity levels, whereas flavonoids content (mainly consisted of quercetin-3-O-glucuronide and kaempferol-3-O-glucuronide) was not affected or slightly increased under high salinity conditions. In contrast, Klados and Tzortzakis (2014) have reported a significant increase in total phenols content with increasing salinity, a difference that could be attributed to different growing conditions, whereas the higher dry matter content reported in that study may indicate more stressful conditions comparing to those in our study that could induce phenolic compounds biosynthesis. Moreover, Zeghichi et al. (2003) expressed total phenols content of C. spinosum leaves in catechin equivalents (16.31-20.31 mg $100 \mathrm{~g}^{-1}$ fresh weight), whereas Vardavas et al. (2006) reported a total polyphenol content of $132 \mathrm{mg} 100 \mathrm{~g}^{-1} \mathrm{f}$.w. In order to quantify the phenolic compounds content these authors performed colorimetric assays and did not performed a detailed identification of the phenolic compounds. Therefore these results are not comparable to the results of the present study.

Antioxidant activity of $C$. spinosum leaves are presented in Table 5. All the treatments showed a high antioxidant activity. However, the mid-to-high salinity treatment gave the best results for all the antioxidant activity assays (DPPH radical scavenging activity, reducing power, $\beta$-carotene bleaching inhibition and TBARS inhibition), while a further increase in nutrient solution salinity resulted in the reduction of antioxidant activity. The high antioxidant activity for this treatment could be attributed to high ascorbic acid, total tocopherols and phenolic acids content, since the bioactive compounds content of edible greens has been confirmed to be positively correlated with antioxidant activity (Pereira et al., 2011). The high antioxidant activity of $C$. spinosum has also been reported by Zeghichi et al. (2003) who estimated 
Table 5

Antioxidant properties of Cichorium spinosum leaves.

\begin{tabular}{lllll}
\hline Treatments & \multicolumn{4}{l}{$\mathrm{EC}_{50}$ values $(\mathrm{mg} / \mathrm{mL})$} \\
\cline { 2 - 5 } & $\begin{array}{l}\text { DPPH radical- } \\
\text { scavenging } \\
\text { activity }\end{array}$ & $\begin{array}{l}\text { Reducing } \\
\text { power }\end{array}$ & $\begin{array}{l}\beta \text {-Carotene } \\
\text { bleaching } \\
\text { inhibition }\end{array}$ & $\begin{array}{l}\text { TBARS } \\
\text { inhibition }\end{array}$ \\
\hline Control & $1.04 \pm 0.02 \mathrm{c}$ & $0.24 \pm 0.01 \mathrm{c}$ & $0.77 \pm 0.01 \mathrm{c}$ & $0.10 \pm 0.01 \mathrm{~b}$ \\
$4 \mathrm{dS} \mathrm{m}^{-1}$ & $1.10 \pm 0.01 \mathrm{~b}$ & $0.27 \pm 0.01 \mathrm{~b}$ & $0.80 \pm 0.02 \mathrm{~b}$ & $0.12 \pm 0.01 \mathrm{a}$ \\
$6 \mathrm{dS} \mathrm{m}^{-1}$ & $0.98 \pm 0.02 \mathrm{~d}$ & $0.22 \pm 0.01 \mathrm{~d}$ & $0.64 \pm 0.01 \mathrm{~d}$ & $0.07 \pm 0.01 \mathrm{c}$ \\
$8 \mathrm{dS} \mathrm{m}^{-1}$ & $1.12 \pm 0.01 \mathrm{a}$ & $0.29 \pm 0.01 \mathrm{a}$ & $0.87 \pm 0.01 \mathrm{a}$ & $0.13 \pm 0.01 \mathrm{a}$ \\
\hline
\end{tabular}

The antioxidant activity was expressed as $\mathrm{EC}_{50}$ values, what means that higher values correspond to lower reducing power or antioxidant potential. $\mathrm{EC}_{50}$ : Extract concentration corresponding to $50 \%$ of antioxidant activity or 0.5 of absorbance in reducing power assay. Trolox $\mathrm{EC}_{50}$ values: $41 \mu \mathrm{g} / \mathrm{mL}$ (reducing power), $42 \mu \mathrm{g} / \mathrm{mL}$ (DPPH scavenging activity), $18 \mu \mathrm{g} / \mathrm{mL}$ ( $\beta$-carotene bleaching inhibition) and $23 \mu \mathrm{g} /$ $\mathrm{mL}$ (TBARS inhibition). In each column different letters mean significant differences between samples $(\mathrm{p}<0.05)$.

ascorbic acid, $\alpha$-tocopherol, $\beta$-carotene, glutathione and total phenolics as the main antioxidants, as well as by Vardavas et al. (2006) who determined vitamin C, lutein, carotenoids and total polyphenols content.

\section{Conclusions}

In conclusion, although significant changes in chemical composition were observed under saline conditions, nutritional value of Cichorium spinosum leaves was very high and based on their antioxidant activity, the mineral composition, and the balanced $\mathrm{n}-6 / \mathrm{n}-3$ ratio they can be a valuable food source in modern diets and contribute significantly to human health. Moreover, phenolic compounds determination showed an abundance of chicoric acid and 5-O-caffeoylquinic acid, compounds that are reported for the first time for this species, to our knowledge. Therefore $C$. spinosum is a species that could be cultivated under saline conditions without compromises in terms of the quality of the final product, and could be a promising alternative crop for farmers, especially in semi-arid areas where irrigation water is scarce and/or of low quality due to high content of $\mathrm{NaCl}$ (coastal areas or areas where underground water is saline).

\section{References}

Arshi, A., Ahmad, A., Aref, I. M., \& Iqbal, M. (2010). Effect of calcium against salinityinduced inhibition in growth, ion accumulation and proline contents in Cichorium intybus L. Journal of Environmental Biology, 31(6), 939-944.

AOAC (2005). In W. Horwitz \& G. Latimer (Eds.), Official methods of analysis of AOAC international (18th ed. Gaithersburg, MD: AOAC International.

Arshi, A., Abdin, M. Z., \& Iqbal, M. (2006). Effect of $\mathrm{CaCl}_{2}$ on growth performance, photosynthetic efficiency and nitrogen assimilation of Cichorium intybus L. grown under $\mathrm{NaCl}$ stress. Acta Physiologia Plantarum, 28(2), 137-147.

Atia, A., Barhoumi, Z., Mokded, R., Abdelly, C., \& Smaoui, A. (2011). Environmental eco-physiology and economical potential of the halophyte Crithmum maritimum L. (Apiaceae). Journal of Medicinal Plants Research, 5(16), 3564-3571.

Camara, B., Bardat, F. Seye, A., D'Harlinge, A., \& Moneger, R. (1982). Terpenoid metabolism in plastids. Localisation of $\alpha$-tocopherol synthesis in capsicum chloroplasts. Plant Physiology, 70, 1562-1563.

Carazzone, C., Mascherpa, D., Gazzani, G., \& Papetti, A. (2013). Identification of phenolic constituents in red chicory salads (Cichorium intybus) by highperformance liquid chromatography with diode array detection and electrospray ionisation tandem mass spectrometry. Food Chemistry, 138 1062-1071.

Chartzoulakis, K. S. (1994). Photosynthesis, water relations and leaf growth of cucumber exposed to salt stress. Scientia Horticulturae, 59(1), 127-135.

Chartzoulakis, K., \& Klapaki, G. (2000). Response of two greenhouse pepper hybrids to $\mathrm{NaCl}$ salinity during different growing stages. Scientia Horticulturae, 86, $247-260$.

Dalar, A., \& Konczak, I. (2014). Cichorium intybus from Eastern Anatolia: Phenolic composition, antioxidant and enzyme inhibitory activities. Industrial Crops and Products, 60, 79-85.

De Pascale, S., \& Barbieri, G. (1995). Effects of soil salinity from long-term irrigation with saline-sodic water on yield and quality of winter vegetable crops. Scienti Horticulturae, 64, 145-157.
FAO (2009). FAO land and plant nutrition management service. http://www.fao.org/ ag/agl/agll/spush/.

Guil, J. L., Torija, M. E., Giménez, J. J., \& Rodriguez, I. (1996). Identification of fatty acids in edible wild plants by gas chromatography. Journal of Chromatography A, 719, 229-235.

Guimarães, R., Barros, L., Dueñas, M., Calhelha, R. C., Carvalho, A. M., Santos-Buelga, S., ... Ferreira, I. C. F. R. (2013). Nutrients, phytochemicals and bioactivity of wild Roman chamomile: A comparison between the herb and its preparations. Food Chemistry, 136, 718-725.

Heimler, D., Isolani, L., Vignolini, P., \& Romani, A. (2009). Polyphenol content and antiradical activity of Cichorium intybus L. from biodynamic and conventional farming. Food Chemistry, 114, 765-770.

Juśkiewicz, J., Zduńczyk, Z., Żary-Sikorska, E., Król, B., Milala, J., \& Jurgoński, A. (2011). Effect of the dietary polyphenolic fraction of chicory root, peel, seed and leaf extracts on caecal fermentation and blood parameters in rats fed diets containing prebiotic fructans. British Journal of Nutrition, 105, 710-720.

Justesen, U., \& Knuthsen, P. (2001). Composition of flavonoids in fresh herbs and calculation of flavonoid intake by use of herbs in traditional Danish dishes. Food Chemistry, 73, 245-250.

Klados, E., \& Tzortzakis, N. (2014). Effects of substrate and salinity in hydroponically grown Cichorium spinosum. Journal of Soil Science and Plant Nutrition, 14(1), 211-222.

Ksouri, R., Ksouri, W. M., Jallali, I., Debez, A., Magné, C., Hiroko, I., \& Abdelly, C. (2011). Medicinal halophytes: Potent source of health promoting biomolecules with medical, nutraceutical and food applications. Critical Reviews in Biotechnology, 32, 289-326.

Lushchak, V. I., \& Semchuk, N. M. (2012). Tocopherol biosynthesis: Chemistry, regulation and effects of environmental factors. Acta Physiologia Plantarum, 34 (5), 1607-1628.

Melliou, E., Magiatis, P., \& Skaltsounis, A. L. (2003). Alkylresorcinol derivatives and sesquiterpene lactones from Cichorium spinosum. Journal of Agricultural and Food Chemistry, 51, 1289-1292.

Morales, P., Carvahlo, A. M., Sánchez-Mata, M. C., Cámara, M., Molina, M. \& Ferreira, I. C. F. R. (2012). Tocopherol composition and antioxidant activity of Spanish wild vegetables. Genetic Resources and Crop Evolution, 59, 851-863.

Mozafar, A. (1993). Nitrogen fertilizers and the amount of vitamins in plants: A review. Journal of Plant Nutrition, 16(12), 2479-2506.

Munne-Bosch, S. (2005). The role of $\alpha$-tocopherol in plant stress tolerance. Journal of Plant Physiology, 162, 743-748.

Nagata, M., \& Yamashita, I. (1992). Simple method for simultaneous determination of chlorophyll and carotenoids in tomato fruit. Nippon Shokuhin Kogyo Gakkaish, 39, 925-928.

Pereira, C., Barros, L., Carvahlo, A. M., \& Ferreira, I. C. F. R. (2011). Nutritional composition and bioactive properties of commonly consumed wild greens: Potential sources for new trends in modern diets. Food Research International, 44, 2634-2640.

Pereira, C., Barros, L., Carvalho, A. M. \& Ferreira, I. C. F. R. (2013). Use of UFLC-PDA for the analysis of organic acids in thirty-five species of food and medicinal plants. Food Analytical Methods, 6, 1337-1344.

Rossetto, M., Lante, A., Vanzani, P., Spettoli, P., Scarpa, M., \& Rigo, A. (2005). Red chicories as potent scavengers of highly reactive radicals: A study on their phenolic composition and peroxyl radical trapping capacity and efficiency. Journal of Agricultural and Food Chemistry, 53, 8169-8175.

Sergio, L., De Paola, A., Cantore, V., Pieralice, M., Cascarano, N. A., Bianco, V. V., \& Di Venere, D. (2014). Effect of salt stress on growth parameters, enzymatic antioxidant system, and lipid peroxidation in wild chicory (Cichorium intybus L.). Acta Physiologiae Plantarum, 36(6), 2349-2358.

Shannon, M. C., \& Grieve, C. M. (1999). Tolerance of vegetable crops to salinity. Scientia Horticulturae, 78, 5-38.

Simopoulos, A. P. (2008). The importance of the omega-6/omega-3 fatty acid ratio in cardiovascular disease and other chronic diseases. Experimental Biology and Medicine, 233(6), 674-688.

Sinkovic, L., Demšar, L., Znidarcic, D., Vidrih, R., Hribar, J., \& Treutter, D. (2015). Phenolic profiles in leaves of chicory cultivars (Cichorium intybus L.) as influenced by organic and mineral fertilizers. Food Chemistry, 166, 507-513.

Tarchoune, I., Sgherri, C., Baâtour, O., Izzo, R., Lachaâl, M., Navari-Izzo, F., \& Ouerghi, Z. (2013). Effects of oxidative stress caused by $\mathrm{NaCl}$ or $\mathrm{Na}_{2} \mathrm{SO}_{4}$ excess on lipoic acid and tocopherols in Genovese and Fine basil (Ocimum basilicum). Annals of Applied Biology, 163(1), 23-32.

Tzortzakis, N. G. (2009). Influence of $\mathrm{NaCl}$ and calcium nitrate on lettuce and endive growth using nutrient film technique. International Journal of Vegetable Science, $15,1-13$.

Ushakova, S. A., Kovaleva, N. P., Gribovskaya, I. V., Dolgushev, V. A., \& Tikhomirova, N. A. (2005). Effect of $\mathrm{NaCl}$ concentration on productivity and mineral composition of Salicornia europaea as a potential crop for utilization $\mathrm{NaCl}$ in LSS. Advances in Space Research, 36, 1349-1353.

Vardavas, C. I., Majchrzak, D., Wagner, K. H., Elmadfa, I., \& Kafatos, A. (2006). The antioxidant and phylloquinone content of wildly grown greens in Crete. Food Chemistry, 99, 813-821.

Ventura, Y., \& Sagi, M. (2013). Halophyte crop cultivation: The case for Salicornia and Sarcocornia. Environmental and Experimental Botany, 92, 144-153.

Yousif, B. S., Nguyen, N. T., Fukuda, Y., Hakata, H., Okamoto, Y., Masaoka, Y., \& Saneoka, H. (2010). Effect of salinity on growth, mineral composition, photosynthesis and water relations of two vegetable crops; New Zealand spinach (Tetragonia tetragonioides) and water spinach (Ipomoea aquatica). International Journal of Agriculture and Biology, 12(2), 211-216. 
Yusuf, M. A., Kumar, D., Rajwanshi, R., Strasser, R. J., Tsimilli-Michael, M., Govindjee \& Sarin, N. B. (2010). Overexpression of gamma-tocopherol methyl transferase gene in transgenic Brassica juncea plants alleviates abiotic stress: Physiological and chlorophyll a fluorescence measurements. Biochimica et Biophysica Acta, 1797, $1428-1438$.
Zeghichi, S., Kallithraka, S., \& Simopoulos, A. P. (2003). Nutritional composition of Molokhia (Corchorus olitorius) and stamnagathi (Cichorium spinosum). World Review of Nutrition and Dietetics, 91, 1-21.

Zhu, J. K. (2001). Plant salt tolerance. Trends in Plant Science, 6, 66-71. 